DOI https://doi.org/10.36059/978-966-397-117-9/120-140

\title{
INTERNATIONAL LEGAL PROTECTION OF PUBLIC PROPERTY RELATIONS: PRACTICAL EXPERIENCE OF THE EUROPEAN COURT OF HUMAN RIGHTS
}

\section{Zadyraka N. Yu.}

\section{INTRODUCTION}

Today, the practice of relation fulfillment in the field of public property use shows exhaustibility of resources, the possibility of system functioning "by inertia" without any systematic and proper legal regulation, that is why it is necessary to create conditions for legitimate, effective and rational use of public property taking into account public interest.

Pragmatism causes rational and effective use of public property. It is reasonable to be guided by democratic principles and pragmatic psychology of public administration subjects and other participants of public property relations during implementation of the tools of public administration activity.

"Three-stage test" in relation to public property use is implemented according to principles of legitimacy, legitimate goal in the interests of democratic society and proportionality (fair balance of interests).

Social dimension of everyday life of the state and society, in particular, in public property use ${ }^{1}$, enshrined in Art. 1, 3, 13, 14 of the Constitution of Ukraine, can be implemented in practice with the view to pragmatic theory of handling and evaluation. It is possible under the condition of dynamic interaction of social-state sector concerning public property use taking into account the experience of the past.

\footnotetext{
${ }^{1}$ Конституція України: Закон від 28.06.1996 р. № 254к/96-ВР: із зм. і доп. станом на 30.09.2016 р. Офіційний вісник України. 2010. № 72/1. Спеціальний випуск. С. 15. Ст. 2598.
} 


\section{Peculiarities of "Three-Stage Test" Implementation in the Public Property Use}

Depending on regime characteristics, "three-stage" test covers the following types of public property of international, national and local purpose having natural or artificial origins ${ }^{2}$ :

1) Closed regime of use: weapons, military machines and military suppliers;

2) Restricted regime of use: gas transportation and pipelines infrastructure, special communication means;

3) General regime of use:

- Property of international significance of natural (such as the Carpathian Mountains, the Black Sea and its water area) or artificial origin (UNESCO World Heritage sites established by the Convention for the Protection of the World Cultural and Natural Heritage $\left.{ }^{3}\right)$;

- Property of national significance of natural (landscape parks, reserves) or artificial origin (museum, memorial complexes) for the purpose of achieving public interest, meeting the legal needs of interests of persons who legally live within a particular country;

- Property of general use of local purpose (air, water, railways, motorways; land owned by territorial communities, property of state and communal enterprises, institutions, organizations, property that provides functioning of public administration subjects, public money, buildings and public premises.

As for fulfillment of legal regimes of the public property types mentioned, then in view of public interest, the principle of legitimate goal is associated with the necessity of interest consideration, in particular, in relation to supervision of property use according to common interests. The legitimate goal in view of public interest may require less than indemnification of full market property $\operatorname{cost}^{4}$ (the decision in the case "James and others v. The United Kingdom"). In $\S 111$ the European Court of Human Rights in the case "Beyeler v. Italy" consolidated the legal position about the limits of law intervention based on the legitimate goal

\footnotetext{
${ }^{2}$ Миронюк Р.В., Пищида В.М. Особливості розгляду спорів, пов’язаних 3 використанням та розпорядженням публічним майном: монографія. Дніпро: Дніпроп. держ. ун-т внутр. справ, 2018. С. 18-20.

${ }^{3}$ Конвенція про охорону всесвітнього культурного і природного спадку: Міжнародний документ, ратифікований Указом Президії Верховної Ради № 6673-XI від 04.10.1988 p. URL: https://zakon.rada.gov.ua/laws/show/995_089 (дата звернення: 04.04.2019).

${ }^{4}$ Справа «James and Others v. the United Kingdom»: рішення Свропейського суду з прав людини від 21.02.1986 р. № 8793/79. URL: http://hudoc.echr.coe.int/eng?i=001-57507 (дата звернення: 04.04.2019).
} 
and purposes of restrictions for which they are established ${ }^{5}$. In fact and by law the participants of public property relations are vested with freedom of discretion to make their decision which goal is legitimate.

Thus, the legitimate goal of public property relations under the "three-stage test" determines the necessity in establishment of mainly mixed, state-corporative economy, a key element of which must be a large multi-sector corporation ${ }^{6}$. Such development is possible by using a category of public functions, which, according to Petrov E. V. is the continuation of the chain of logically connected definitions: public law public interest - public management - public administration - public functions ${ }^{7}$.

Therefore, the existence of legitimate goal allows achieving primary goal of public property management. As O. V. Kuzmenko mentioned, the reasons, the conditions and the outcome of such activity manifests itself in the system of coordinated mechanism of supervision, generalization of official positions and organizational units, establishment of generalized indexes of effectiveness and in proper mutual agreement ${ }^{8}$. In such a way the public administration in public property relations obtains a possibility to satisfy public interest taking into account common interest.

"Public interest" category is a fundamental reference point in establishment of goal legitimacy of public property use. For example, in the case of "Former King of Greece and others v. Greece" the European Court of Human Rights detected the following circumstances of the case. The applicants, members of the royal family, argued that the legislative measure deprived them of ownership of certain lands in Greece. The Government argued that legitimate interests of the state are in the need to protect forests and archaeological sites within these estates. An additional argument was that the disputed legislation was associated with a great public interest in preserving the constitutional status of the country as a republic. The European Court of Human Rights noted that there was not any evidence to support the Government's argument regarding the need to

\footnotetext{
${ }^{5}$ Справа «Beyeler v. Italy»: рішення Європейського суду 3 прав людини від 05.01.2000 p. № 33202/96. URL: http://hudoc.echr.coe.int/eng?i=001-58832 (дата звернення: 04.04.2019).

${ }^{6}$ Публічна власність : проблеми теорії і практики: монографія / під заг. ред. В.А. Устименка ; НАН України, Ін-т економіко-правових досліджень. Чернігів: Десна Поліграф, 2014. С. 33.

${ }^{7}$ Петров Є.В. До питання про зміст категорії «публічна адміністрація». Південноукраӥнський правничий часопис. 2012. № 3. С. 6-7.

${ }^{8}$ Кузьменко О.В. Правова детермінація поняття «публічне адміністрування». Юридичний вісник. Повітряне і космічне право. 2009. № 3. С. 23.
} 
protect forests or archaeological sites. On the other hand, in view of the fact that the disputed law was adopted almost 20 years after Greece became a republic, the state should regulate a clear set of obstacles for its status ${ }^{9}$.

As a result, the public service model of the state is implemented, based on the organizational and legal coordinated methods of the public administration mechanism, defining the goals of the public administration activity and structure, as well as establishing rights, powers and ensuring the implementation of measures of liability ${ }^{10}$.

We propose to be governed by "pure" understanding of legal regime through abstraction, exclusion and differentiation of moral, ethical, psychological, sociological, and other elements of the relations in public property use. Therefore, the concepts of "law" and "legal act" are identical for establishment of the content of legal norms as norms of obligation in accordance with the criteria of validity and effectiveness ${ }^{11}$. Effectiveness characterizes the legal regime of public property, in case of application of relevant legal norms regarding the actual public property use, which complies with these norms. The validity is related to the actual implementation of legal regime. At the same time, this legal regime is objectively valid, when the use of public property, which it sets, in fact, at least partially corresponds to the regime characteristics of public property.

We should specify that Article 1 of Protocol № 1 of the Convention for the Protection of Human Rights and Fundamental Freedoms establishes three individual rules for property use ${ }^{12}$. Thus, the first rule, having a general character, indicates the principle of peaceful property use. The above rule is set out in the first sentence of the first paragraph of Article 1 of Protocol № 1. The second rule regulates the procedure for deprivation of property under prescribed conditions. This approach is set out in the second sentence of the same paragraph. The third rule stipulates that states have the right, among other things, to control the property use

\footnotetext{
${ }^{9}$ Справа «Former King of Greece and Others v. Greece»: рішення Свропейського суду з прав людини від 23.11.2000 p. № 25701/94. URL: http://hudoc.echr.coe.int/eng?i=001-59051 (дата звернення: 04.04.2019).

${ }^{10}$ Легеза Ю.О. Завдання та функції публічного управління у сфері використання природних ресурсів. Науковий вісник Міжнародного гуманітарного університету. 2017. Вип. 26. С. 20 (Серія: Юриспруденція).

${ }^{11}$ Ковтонюк А.М. Ганс Кельзен і його чиста теорія права. Університетські наукові записки. 2007. № 1. C. 29-30.

${ }^{12}$ Конвенція про захист прав людини та основоположних свобод: Міжнародний документ від 04.11.1950 р. Офіційний вісник України. 2006. № 32. С. 270.
} 
in accordance with common interests by executing such laws as they deem necessary for this purpose. This rule is contained in the second paragraph.

The approach of the European Court of Human Rights in dealing with property rights cases is not always the same. For example, after clarifying the fact that Article 1 of Protocol № 1 is applicable, the court sometimes determines whether this measure is a deprivation of property or rather falls under the control of use ${ }^{13}$ (the decision in the case "Suljagic v. Bosnia and Herzegovina"). In other cases, the European Court of Human Rights does not make this differentiation, but claims that it considers a certain measure, taking into account the provisions of Article 1, Protocol № 1 and the principles governing the property right $^{14}$ (the decisions in the cases "Beyeler v. Italy", § 106; «Broniowski v. Poland", § 136).

A further illustration of what might constitute an asset and, consequently, "property" is the case of "Pressos Compania Naviera SA and others v. Belgium" ". In this case, the applicants were the owners of ships whose ships were involved in collisions in the territorial waters of Belgium. The collision occurred because of the negligence of Belgian marine pilots, for which, according to Belgian law, the state is responsible. However, in August 1988, the Belgian legislative body adopted a law that exempts the state from liability with retrospective effect. The applicants complained under Art. 1, Protocol № 1 that their right to property had been violated. The state argued that the applicants had no "property" within the meaning of this article. The court noted that claims for compensation were brought in compliance with Belgian tort law when the damage took place. Thus, such requirement was an asset and was considered as "possession"16. Based on court case law before the adoption of new legislation, the applicants could argue that the national courts could make decisions in their favor.

\footnotetext{
${ }^{13}$ Справа «Suljagic v. Bosnia and Herzegovina»: рішення Свропейського суду з прав людини від 03.02.2010 p. № 27912/02. URL: http://hudoc.echr.coe.int/eng?i=001-95564 (дата звернення: 04.04.2019).

${ }^{14}$ Справа «Beyeler v. Italy»: рішення Європейського суду 3 прав людини від 05.01.2000 p. № 33202/96. URL: http://hudoc.echr.coe.int/eng?i=001-58832 (дата звернення: 04.04.2019).; Справа «Broniowski v. Poland»: рішення Свропейського суду з прав людини від 28.09.2005 р. № 31443/96. URL: http://hudoc.echr.coe.int/eng?i=001-70326 (дата звернення: 04.04.2019).

${ }^{15}$ Справа «Pressos Compania Naviera S.A. and Others v. Belgium»: рішення Європейського суду 3 прав людини від 20.11.1995 р. № 17849/91. URL: http://hudoc.echr.coe.int/eng?i=001-58056 (дата звернення: 04.04.2019).

${ }^{16}$ Справа «Pressos Compania Naviera S.A. and Others v. Belgium»: рішення Свропейського суду 3 прав людини від 20.11.1995 p. № 17849/91. URL: http://hudoc.echr.coe.int/eng?i=001-58056 (дата звернення: 04.04.2019).
} 
Considering the European practice in relation to peculiarities of the public property use by the criterion of public interest in detail, we should note that Article 1 of the Convention for the Protection of Human Rights and Fundamental Freedoms, first of all, stipulates the provisions of "property use"17. The use can be defined as the ability to use public property according to its purpose. As an example of the case, "Sporrong and Lönnroth v. Sweden", it was recognized that prohibitions on construction hindered the property use ${ }^{18}$. At the same time, a complete set of principles for the property use can not be identified. So, the owner may be legally obliged to perform certain actions in relation to public property.

So, the rights to public property can not be considered as absolute. The prohibition on ownership of certain things is another way of introducing the principles of exercising property rights. This approach was adopted in the case "Handyside v. The United Kingdom", where confiscation was permitted under the Convention on the grounds, that things are prohibited by law and constitute danger to the common interest $^{19}$. According to the general rule, the public property use gives the owner the exclusive right to his property. For example, in the case "Kleine Staarman v. The Netherlands", it was established that the owner had to have an identified, pretending and, therefore, exclusive claim of joint capital to obtain the right to possession. The lack of exclusivity ("identified and claim share") may be a ground for refusal to satisfy claims ${ }^{20}$.

The right to dispose of public property can be regarded as a traditional and fundamental aspect of property rights. This right allows the owner of public property to enter into legal relations with other persons, regardless of the form of relations: sale, lease, and usufruct. Such interchangeability can be considered as the most important condition of economic efficiency and justice. The right to dispose of property means that such property is an asset. The criterion of economic value may be

\footnotetext{
${ }^{17}$ Конвенція про захист прав людини та основоположних свобод: Міжнародний документ від 04.11.1950 р. Офіційний вісник України. 2006. № 32. С. 270.

${ }^{18}$ Справа «Sporrong and Lönnroth v. Sweden»: рішення Європейського суду 3 прав людини від 23.09.1982 p. №№ 7151/75; 7152/75. URL: http://hudoc.echr.coe.int/eng?i=001-57580 (дата звернення: 04.04.2019).

${ }^{19}$ Справа «Handyside v. the United Kingdom»: рішення Європейського суду 3 прав людини від 07.12.1976 р. № 5493/72. URL: http://hudoc.echr.coe.int/eng?i=001-57499 (дата звернення: 04.04.2019).

${ }^{20}$ Справа «Kleine Staarman v. the Netherlands»: рішення Свропейського суду з прав людини від 16.05 .1985 p. № 10503/83. URL: https://hudoc.echr.coe.int/app/conversion/pdf?library=ECHR\&id=001 73885\&filename=F.P.J.M.\%20KLEINE\%20STAARMAN\%20v.\%20the\%20NETHERLANDS.pdf （дата звернення: 04.04.2019).
} 
used to establish ownership presence. In particular, in the case "Bramelid and Malmström v. Sweden", it was examined whether the shares of company were in ownership. It has been determined that the company's share is a complex category: it confirms that the owner owns the rights (especially the right to vote); is an indirect claim to the assets of the company $^{21}$. Thus, the shares have an economic value because they are the property.

Public interest in public property relations determines rules for the peaceful property use. As an example in the case "Sporrong and Lönnroth v. Sweden", it was recognized that the availability of permits for expropriation led to reduction in the selling price of the property considered. However, the applicants never ceased to be the owners, and they could always dispose of it. Thus, the general rule for guaranteeing the peaceful possession of property was implemented ${ }^{22}$.

When a person is deprived of a public property or rights to it, a category of public interest is also used to justify the legality and appropriateness of the said actions. Thus, in the case "Papamichalopoulos and others v. Greece", the applicants' valuable land was seized by the state in 1967 during the dictatorial period and transferred to the Navy, which then created a naval base in place. Since, after this time, the applicants could not effectively use their property or alienate it, the state was prosecuted for actual expropriation ${ }^{23}$. In the case "Brumărescu v. Romania", the applicant, based the decision of the court of first instance in his favor, returned the pre-nationalized property into his ownership. Later on, the Supreme Court revoked the decision of the court of first instance, as a result of which the applicant no longer had the right to use this property. The European Court of Human Rights, when considering and resolving the dispute over the lawfulness of the property possession within the meaning of Article 1 of Protocol № 1, was guided by the second rule of this provision ${ }^{24}$.

\footnotetext{
${ }^{21}$ Справа «Lars Bramelid and Anne Marie Malmström against Sweden»: рішення Комітету Міністрів від 25.10.1984 р. №№ 8588/79; 8589/79. URL: https://hudoc.echr.coe.int/eng\# \{"tabview":["document"], "itemid":["001-49253"]\} (дата звернення: 04.04.2019).

${ }^{22}$ Справа «Sporrong and Lönnroth v. Sweden»: рішення Європейського суду з прав людини від 23.09.1982 p. №№ 7151/75; 7152/75. URL: http://hudoc.echr.coe.int/eng?i=001-57580 (дата звернення: 04.04.2019).

${ }^{23}$ Справа «Рараmichalopoulos and Others v. Greece»: рішення Свропейського суду з прав людини від 24.06.1993 р. № 14556/89. URL: http://hudoc.echr.coe.int/eng?i=001-57836 (дата звернення: 04.04.2019).

${ }^{24}$ Справа «Brumărescu v. Romania»: рішення Свропейського суду з прав людини від 28.10.1999 р. № 28342/95. URL: http://hudoc.echr.coe.int/eng?i=001-58337 (дата звернення: 04.04.2019).
} 
Public interest also manifests itself in relation to the supervision over the public property use. In the case "Mellacher and others v. Austria", it was stated that a measure to reduce the legal payments to property owners could be considered as the supervision over the property use in accordance with the recently adopted $\operatorname{law}^{25}$. For example, the case "Handyside v. The United Kingdom", it was established that the temporary seizure of property did not involve deprivation of property. Therefore, the third rule of Article 1 of Protocol №1 is applicable ${ }^{26}$.

In fact, the supervision over the public property use should take place in the interest of society. Article 1 of the Convention for the Protection of Human Rights and Fundamental Freedoms provides that supervision concerns the property $u^{27}$. In practice, this may relate to the right to dispose of property. Thus, restrictions on freedom of entry into contractual relations can be the supervision over the property use. Similarly, intervention in exclusivity is an intervention in the property use, and therefore, in property.

The case "Svenska Managamentgruppen AB v. Sweden" proves it. The applicant had property on the shore of the lake, which gave him the exclusive right to fishing. Later on the above mentioned right was canceled by law. It was acknowledged that this right could be considered as ownership and that its revocation was an intervention in property rights $^{28}$. At the same time, such an intervention is not a deprivation of property, but it is supervision over the property use.

Taking into account the above mentioned positions on public interest in public property relations, it is important for their protection to be appropriate. First of all, there should be an optimal model of administrative justice that is consistent with public interest. Legal protection in order to ensure the exercise of human rights and freedoms must be carried out by an independent and competent authority. As a rule, in relations with the authorities such entity is a judicial authority, since

\footnotetext{
${ }^{25}$ Справа «Mellacher and Others v. Austria»: рішення Європейського суду 3 прав людини від 19.12.1989 p. №№ 10522/83; 11011/84; 11070/84. URL: http://hudoc.echr.coe.int/eng?i=001-57616 (дата звернення: 04.04.2019).

${ }^{26}$ Справа «Handyside v. the United Kingdom»: рішення Свропейського суду з прав людини від 07.12.1976 p. № 5493/72. URL: http://hudoc.echr.coe.int/eng?i=001-57499 (дата звернення: 04.04.2019).

${ }^{27}$ Конвенція про захист прав людини та основоположних свобод: Міжнародний документ від 04.11.1950 р. Офіційний вісник України. 2006. № 32. С. 270.

${ }^{28}$ Справа «Svenska Managamentgruppen $\mathrm{AB}$ v. Sweden»: рішення Європейського суду 3 прав людини від 01.12 .1985 р. № 11036/84. URL: https://hudoc.echr.coe.int/app/conversion/pdf?library= ECHR\&id=001-72454\&filename=SVENSKA\%20MANAGEMENTGRUPPEN\%

20AB\%20v.\%20SWEDEN.pdf (дата звернення: 04.04.2019).
} 
such a subject may influence the implementation of public administration responsibility for its activities.

Therefore, in functioning of the administrative justice national model in relation to public property, it is essential to consider the legitimacy and proportionality of restrictions when implementing the legal regime of public property, both from the point of view of supranational and national law. The provisions of "pure theory" by H. Kelsen are the corresponding law-enforcement and methodological reference point. In particular, it is about the perception of national legal systems and international law as the whole, a hierarchical system that goes back to the so-called Grundnor ${ }^{29}$. The fundamental factor of legitimacy is a category of democracy ${ }^{30}$ that is, the reasonability of establishing and ensuring the democratic dimension of the legal regime implementation of public property. On this occasion, the criterion of the regime democratic nature is acceptable, analogically to the concept of democratic coup d'etat. Thus, Ozan O. Varol formulated the criteria relating to the legitimacy of power in general, as well as the compromise nature of interaction between the parties to the relations, the "transfer" of power".

According to the "three-stage test", a democratic dimension of the legal regime implementation of public property is impossible without clear establishment of boundaries for public administration activity. It is through organizational management, control and supervisory tools of public administration that one can optimize the model of public administration regarding the public property use, strengthen social dialogue and partnership, and increase the level of trust of the world community in Ukraine.

A key limiting factor for the public administration implementation in the implementation of legal regime of public property should be the principle of fair balance. Thus, the interests of a person who has suffered as a result of intervention in the rights to property must take into account the interests of the general public. Intervention should not impose excessive or disproportionate burden on a person ${ }^{32}$. In fact, there must be a balance between public and private interests in order to prevent arbitrary

\footnotetext{
${ }^{29}$ Kelsen H. General Theory of Law and State. Harvard: Harvard University Press. 2009. 516 p.

${ }^{30}$ D'Aspermont J. Responsibility for Coups d'Etat in International Law. Tulane Journal of International and Comparative Law. 2010. № 18. P. 45.

${ }^{31}$ Varol O.O. The Democratic Coup d'Etat. Harvard International Law Journal. 2012. № 53. P. 297.

${ }^{32}$ Справа «Valkov and Others v. Bulgaria»: рішення Європейського суду 3 прав людини від 25.10.2011 p. № 2033/04, 19125/04, 19475/04, 19490/04, 19495/04, 19497/04, 24729/04, 171/05, 2041/05. URL: http://hudoc.echr.coe.int/eng?i=001-107157 (дата звернення: 04.04.2019).
} 
interference that does not comply with the law. In the case "Jahn and others v. Germany, the European Court of Human Rights clearly stated that exceptional circumstances, such as the unique context of reunification of Germany, could justify the absence of any compensation to private law subjects as a result of intervention in their property rights ${ }^{33}$.

The proportionality of restrictions for the public administration implementation during implementation of public property legal regime is manifested in compliance with the requirements of Article 1, Protocol № 1 of the Convention for the Protection of Human Rights and Fundamental Freedoms ${ }^{34}$.

An example might be the case "Hentrich v. France", in which the applicant had purchased the land, on which the state authorities subsequently wanted to exercise their priority right. The state argued that public interest in this case is to prevent tax evasion ${ }^{35}$. The European Court of Human Rights came to the conclusion that exemption by the state can be predictable, both arbitrary and selective. In the given circumstances of the case, the applicant experienced an individual and excessive burden which could be legitimate only if he was denied an effective appeal against the measure taken against him. Therefore, the fair balance was violated that had to be achieved between property right protection and requirements of public interest ${ }^{36}$.

Accordingly, public interest in public property relations determines negative and positive obligations of the state. In accordance with $\S 37$ of the European Court of Human Rights decision in the case "Carmel Saliba v. Malta" any intervention by a public administration subject in the right to peaceful possession of property should be legal ${ }^{37}$. That is, illegal intervention in the owner's property rights is absolutely unacceptable. In view of social justice, this can be achieved through the proper implementation of the public property legal regime and protection of violated, unrecognized or impaired rights, freedoms and legitimate

\footnotetext{
${ }^{33}$ Справа «Jahn and Others v. Germany»: рішення Європейського суду 3 прав людини від 30.06.2005 p. № 46720/99, 72203/01， 72552/01. URL: http://hudoc.echr.coe.int/eng?i=001-69560 (дата звернення: 04.04.2019).

${ }^{34}$ Справа «Scollo v. Italy»: рішення Європейського суду 3 прав людини від 28.09.1995 p. № 19133/91. URL: http://hudoc.echr.coe.int/eng?i=001-57936 (дата звернення: 04.04.2019).

${ }^{35}$ Справа «Hentrich v. France»: рішення Європейського суду з прав людини від 22.09.1994 p. № 13616/88. URL: http://hudoc.echr.coe.int/eng?i=001-57903 (дата звернення: 04.04.2019).

${ }^{36}$ Справа «Hentrich v. France»: рішення Європейського суду 3 прав людини від 22.09 .1994 p. № 13616/88. URL: http://hudoc.echr.coe.int/eng?i=001-57903 (дата звернення: 04.04.2019).

${ }^{37}$ Справа «Carmel Saliba v. Malta»: рішення Свропейського суду з прав людини від 29.11.2016 p. № 24221/13. URL: http://hudoc.echr.coe.int/eng?i=001-169057 (дата звернення: 04.04.2019).
} 
interests. In view of public interest, it is necessary to create conditions for minimizing possible negative manifestations of illegal public property use or unlawful inaction of authorized subjects of public administration. We suggest personalizing the measures of liability taken against the offenders and specifying the penalties for delinquency. This can be achieved based on combination of enforcement power of law provisions with public opinion in order to maintain the state of public order and discipline.

\section{Useful Result of Public Property Relation}

In the theory of pragmatism W. James considers the category of "useful result" as "a state of mind" 38 . We propose to interpret this approach as a reference point for the establishment and development of relations concerning the use of public property, taking into account the ethical and moral principles of such relations, the attitude of public administration and subjects of private law to social reality. The proposed option of implementation of public property relations is implemented in order to ensure social welfare. According to S.S. Kravchenko, one can distinguish the following theoretical priorities of the philosophical movement of legal realism, based on the ideas of classical pragmatism ${ }^{39}$ : power and economics in society; society's welfare; a practical approach to a durable result; a synthesis of legal philosophies.

It can be achieved through the well-established legal regime of public property. As N.V. Kovalenko explains, such regime appears as the main means by which the administrative-legal regulation is implemented, representing the form of state influence on certain domains of public relations, including the economy, in order to coordinate, correlate and eliminate discrepancies in public and private interests ${ }^{40}$. The public dimension of public property relations has a "vertical" nature, aimed at protecting, at first, public interest.

In pragmatic dimension, when formulating the criteria for institutionalization of the public property legal regime, it is necessary to take into account the social life realities of public property relations, based on which the management efficiency evaluation of such property is carried out. The reality of such criteria is manifested in their objectivity

\footnotetext{
${ }^{38}$ James W. What is Pragmatism?. / ed. by A. Blunden. USA: Harvard UP, 2005. P. 29.

${ }^{39}$ Кравченко С.С. Взаємозв'язок теорії правового реалізму і правового прагматизму у філософії США. Актуальні проблеми держави і права. 2011. Вип. 60. С. 475.

${ }^{40}$ Коваленко Н.В. Методологічні підходи до визначення поняття адміністративно-правового режиму. Науковий вісник Дніпропетровського державного університету внутрішніх справ. 2014 . № 1. C. 174 .
} 
and independence in evaluating legal facts based on world-wide views, cultural characteristics, and experience in the relevant field of legal regulation. Namely, taking into account the categories of objectivity, factual assurance and cause and effect links of relations regarding the lawful use of public property during the establishment of powers of public administration subjects and users of public property, the autonomy of the legal status of participants in administrative legal relations regarding the use of public property and administrative -legal ways of protection in this field. Such systemic-structural links allow guaranteeing the effectiveness of public administration activities in the exercise of their powers, taking into account the legal regime of public property on the basis of unified standardization norms and rules of conduct.

In an instrumental dimension, public administration functions in relation to public property have an optimal alternative nature. It is about the reasonability of choosing an optimal way of using property from all available alternatives. At the same time, the probable results of the proposed choice are implemented in new social circumstances. When using public property, the behavior should be oriented towards a longterm relations taking into account a public interest, as well as previous experience in public administration. This process is influenced by the historical context, objective circumstances of public property relations, subjective convictions of persons with legitimate competence to use such property, the existence of liability institution of public administration subjects for torts in public property relations.

As for draft decisions at using public property, then pragmatism allows developing an optimal model of property use, given the potential practical consequences and direct actual current results. As J. Dewey explains, the pragmatic concept of the instrumental method is based on value dimensions, provided that it takes into account practical interest and subjective choice in order to transform undesirable, unfavorable, indefinite, problematic situation into a clear and desirable one for a person $^{41}$. In particular, the standard of justification and legitimacy of public property use should be based on the criterion of effectiveness. It is worth supporting W. James' position that empiricism and rationalism are combined in pragmatism, provided that the experience has practical

\footnotetext{
${ }^{41}$ Скотний П.В. Економіко-теоретичне знання в методологічних рефлексіях прагматизму. Науковий вісник Національного лісотехнічного університету України. 2010. Вип. 20.12. С. 250.
} 
consequences (the criterion of truth is something that "works" best and combines with the whole set of experience) ${ }^{42}$.

Therefore, in order to determine the optimal and most favorable directions of using public administration activity tools in using public property, it will be appropriate to consider the category of usefulness. We agree with the scientific position of $\mathrm{W}$. James that the practical value of true ideas originates from the practical value of their objects ${ }^{43}$. We suggest taking into account the possibility of achieving public interest, meeting the social life needs in rational and efficient use of public property. It is possible in the form of a purposeful, useful for the state and society implementation of public property relations under the conditions of adaptation to the current national economic situation.

As an example, the experience of the Federal Republic of Germany in relation to improving the procedure of public finance use may be relevant for implementation in Ukraine. It is about the possibility of using a privatization tool to increase revenues and reduce the expenses of state and local budgets. Thus, the German practice of law enforcement is guided by the general economic postulate that funds have a more productive potential when used by the subject of private law ${ }^{44}$.

Key innovations should create conditions for the development of corporate transparency in public property use. Given the German experience for Ukraine, it is useful to create a state register that will cover international coverage data. Key innovations should create conditions for the development of corporate transparency in the use of public property. It is useful to create a state register that will cover international coverage data in Ukraine, taking into account the German experience for Ukraine ${ }^{45}$. Of course, it is necessary to ensure full access to data on public expenses and expenses of local self-government bodies, private law and delegated competency subjects that use public property. An appropriate tool for ensuring transparency is the Global registry of owners and other authorized entities on public property.

Note that in implementing public property relations, it is reasonable to take into account the rational sense of C. Peirce's conception on ways of using public property and "possible practical consequences". The

\footnotetext{
42 Джеймс В. Прагматизм. Київ: Вид-во «Украина», 1995. С. 44.

43 Джеймс В. Прагматизм. Київ: Вид-во «Украина», 1995. С. 101.

${ }^{44}$ Welfens P.J.J. Economic Aspects of German Unification: National and International Perspectives. Berlin: Springer Verlag, 1992. P. 245.

${ }^{45}$ Germany: Trend toward re-municipalisation of energy sector. URL: https://www.epsu.org/article/ germany-trend-toward-re-municipalisation-energy-sector (дата звернення: 04.04.2019).
} 
categories of existence, quality, attitude, ideas, and substance are used ${ }^{46}$. The above mentioned means that there is an abstract description of an effective model of person's behavior authorized to use public property.

Thus, the notion of existence is formed when relations on the use of public property arise, in particular, when applying the tools of public administration (ontological proposal). Then, the category of existence is transformed into a qualitative state of relations. That is, relations on the public property use are manifested both directly in the interaction of public administration with other subjects of public and private law, and with no regard to specific circumstances as for institutional characteristics of public property.

Along with that, we should note that often non-compliance with or violation of effectiveness of public property use takes place. For example, there may be torts regarding the use of public money to finance the activity of property of state and communal enterprises, institutions and organizations. The above situation is connected with violation of the obligation by public administration subject to ensure the implementation of the right, established in Art. 53 of the Constitution of Ukraine, to education $^{47}$, an integral element of which is the proper financing of educational institutions. It is about ensuring proper financing of educational institutions, when the receipt of specially allocated money is one of elements of education availability. It is carried out at the expense of the state and local budgets transferring to the specially allocated amount of money in the size of the financial standard to such an educational institution (taking into account the correction coefficients) of budgetary provision per one pupil who acquires a complete general secondary education ${ }^{48}$.

It should be noted that in view of pragmatism it is important for the court to control decisions made on the basis of exercise of discretionary powers as effectively as possible ${ }^{49}$ in disputes concerning the unlawful use of public property and restoration of social welfare (the decision in the case "Hasan and Chaush v. Bulgaria").

\footnotetext{
${ }^{46}$ Пирс Ч.С. Избранные философские произведения / пер. с англ. К. Голубович и др.; ред. Л. Макеева и др. Москва: Логос, 2000. С. 103.

${ }^{47}$ Конституція України : Закон України від 28.06.1996 № 254к/96-ВР : із зм. і доп. станом на 30.09.2016. Офіиійний вісник Украӥни. 2010. № 72/1. Спеціальний випуск. С. 15. Ст. 2598.

${ }^{48}$ Постанова Верховного Суду у складі колегії суддів Касаційного адміністративного суду у справі № 442/8337/17 від 26.02.2019 p. URL: http://www.reyestr.court.gov.ua/Review/80167815 (дата звернення: 04.04.2019).

${ }^{49}$ Справа «Hasan and Chaush v. Bulgaria»: рішення Свропейського суду з прав людини. № 30985/96. URL: http://hudoc.echr.coe.int/eng?i=001-58921 (дата звернення: 04.04.2019).
} 
It is essential to regulate in the Code of Administrative Offences of Ukraine and in the Law of Ukraine "On Management of State-Owned Objects" in detail a procedure for bringing to the liability of public administration subjects for damage, illegal actions, negligence in relation to public property. It is necessary to take into account the fact that, as S. G. Stetsenko emphasized that administrative delictology should be included in the subject of administrative law ${ }^{50}$. According to T. O. Kolomoets, today, administrative-tort relations should belong to the subject of administrative law, since administrative-tort law is not vested with all necessary features of an independent branch of $\operatorname{law}^{51}$. Accordingly, in view of public interest for the proper performance of functions of the state and local self-government as well as other subjects of private law as for the use of public property, administrative and property liability measures should be applied.

Complex implementation of organizational, organizationaladministrative, administrative, and economic means of influencing public property relations will allow realizing public interest in economically rational and legally legitimate use of national property of Ukraine, state resources and capital of territorial communities depending on the purpose of such property. Accordingly, it will be possible to focus on the result of public management activities in terms of maintaining welfare and national law and order, improving and increasing the efficiency of social production, ensuring social dialogue and increasing the investment attractiveness of public property activities.

It can be said that pragmatism determines rational and effective public property use. In such way, officials (officers) of public administration subjects are obliged to provide protection, fair and effective public property use only for implementation of competence provided by law, for prevention of damage. Therefore, public administration subjects' behavior should be guided by observance of anticipated effectiveness from property use, rational decision-making, prevention of excessive costs, as well as taking into account public interests and private goals of a person as a user of public property together with provision of social welfare.

\footnotetext{
${ }^{50}$ Стеценко С.Г. Сучасний погляд на предмет адміністративного права. Публічне право. 2016. № 1. C. 24-25.

${ }^{51}$ Коломоец Т.А. Предмет административного права: к вопросу поиска нового формата в современной украинской административно-правовой науке. Административное право: развитие теоретических основ и модернизация законодательства. 2013. Вып. 8. С. 118 (Серия: Юбилеи, конференции, форумы).
} 


\section{CONCLUSIONS}

One can state that "three-stage test" allows achieving balance between public interest and private interests of persons used public property. This can be achieved in accordance with principles of legitimacy, legitimate goal in the interests of democratic society and proportionality in public property relations. Not less important is to provide preventive and punitive influence of liability of public administration subjects in public property relations. As a result, it is possible to enforce the legitimacy of public administration subjects' activity, support of public effect from penalties taking into account proportional reaction on torts, unlawfulness inaction etc.

Therefore, we suggest the following format of public property use in pragmatic dimension:

- Guaranteeing non-discriminatory use of public property by all authorized representatives of the relations: public administration, other subjects of public and private law;

- Establishing the boundaries of public administration discretion regarding public property and exceptions to the implementation of legal regimes of such property in view of social circumstances, usefulness category and optimal models of draft decisions when using public property;

- Guaranteeing effective means of protecting violated, unrecognized or impaired rights and legitimate interests, in particular, through the right to access to justice; maintaining the unity of legal positions in cases relating to public property that are in court consideration.

Pragmatism allows providing multidimensional nature and flexibility of relations of public property use. As a result, the conditions for mutually accepted and non-controversial decisions, implementation of proper instruments of public administration activities are used.

\section{SUMMARY}

The regime characteristics of types of public property of international, national and local purpose are specified. It is suggested focusing on "pure" understanding of legal regime through abstraction, exclusion and differentiation of moral, ethical, psychological, sociological, and other elements of the relations in public property use. It is justified that public interest exists in public property relations, first of all, in economic measures and it is aimed at achieving social justice and social dialog. 
The article describes the peculiarities of pragmatism methodology implementation to provide rational and effective public property use. The author specifies that it is necessary to guarantee the improvement of ways and "possible practical outcomes" of public administration functions, in particular, practical implementation of draft decision in order to establish and develop the relations of public property use. The attention is drawn to the approaches of scientific school of pragmatism with the aim to formulate the mechanism of making mutually acceptable and noncontroversial decisions, the implementation of proper tools of public administration activity.

The author draws attention to the fact that "three-stage test" allows reaching balance between public interest and private interest of people who use public property according to the principles of legitimacy, legitimate goal in the interest of democratic society and proportionality in public property relations. The practical experience of the European Court of Human Rights, in particular, in relation to rules and principles of peaceful use of public property is analyzed. It is proved that the supervision over public property use should take place in the interests of society.

\section{REFERENCES}

1. Джеймс В. Прагматизм. Київ: Вид-во «Украина», 1995. 284 с.

2. Коваленко Н.В. Квадранти ефективного розвитку економіки України. Актуальні проблеми державного управління. 2016. № 2. C. 81-86.

3. Коваленко Н.В. Методологічні підходи до визначення поняття адміністративно-правового режиму. Науковий вісник Дніпропетровського державного університету внутрішніх справ. 2014. № 1. C. $170-177$.

4. Коломоец Т.А. Предмет административного права: к вопросу поиска нового формата в современной украинской административноправовой науке. Административное право: развитие теоретических основ и модернизация законодательства. 2013. Вып. 8. С. 113-118 (Серия: Юбилеи, конференции, форумы).

5. Конвенція про захист прав людини та основоположних свобод: Міжнародний документ від 04.11.1950 р. Офіиійний вісник Украӥни. 2006. № 32. С. 270.

6. Конвенція про охорону всесвітнього культурного i природного спадку: Міжнародний документ, ратифікований Указом 
Президії Верховної Ради № 6673-XI від 04.10.1988 p. URL: https://zakon.rada.gov.ua/laws/show/995_089 (дата звернення: 04.04.2019).

7. Конституція України: Закон від 28.06.1996 р. № 254к/96-ВР: із зм. і доп. станом на 30.09.2016 р. Офіиійний вісник України. 2010. № 72/1. Спеціальний випуск. С. 15. Ст. 2598.

8. Кузьменко О.В. Адміністративний процес у парадигмі права : автореф. дис. ... д-ра юрид. наук: 12.00.07 / Київ. Нац. ун-т внутр. справ. Київ, 2006. 32 с.

9. Кузьменко О.В. Правова детермінація поняття «публічне адміністрування». Юридичний вісник. Повітряне $i$ космічне право. 2009. № 3. C. 20-24.

10. Легеза Ю.О. Завдання та функції публічного управління у сфері використання природних ресурсів. Науковий вісник Міжнародного гуманітарного університету. 2017. Вип. 26. С. 20-22 (Серія: Юриспруденція).

11. Миронюк Р.В., Пищида В.М. Особливості розгляду спорів, пов'язаних 3 використанням та розпорядженням публічним майном: монографія. Дніпро: Дніпроп. держ. ун-т внутр. справ, 2018. 156 с.

12. Петров С.В. До питання про зміст категорії «публічна адміністрація». Південноукрайнський правничий часопис. 2012. № 3. C. 5-7.

13. Пирс Ч.С. Избранные философские произведения / пер. с англ. К. Голубович и др. ; ред. Л. Макеева и др. Москва: Логос, 2000. $448 \mathrm{c}$.

14. Постанова Верховного Суду у складі колегії суддів Касаційного адміністративного суду у справі № 442/8337/17 від 26.02.2019 p. URL: http://www.reyestr.court.gov.ua/Review/80167815 (дата звернення: 04.04.2019).

15. Публічна власність : проблеми теорії і практики: монографія / під заг. ред. В.А. Устименка ; НАН України, Ін-т економікоправових досліджень. Чернігів: Десна Поліграф, 2014. 308 с.

16. Скотний П.В. Економіко-теоретичне знання в методологічних рефлексіях прагматизму. Науковий вісник Національного лісотехнічного університету України. 2010. Вип. 20.12. С. 247-255.

17. Справа «Belvedere Alberghiera S.r.l. v. Italy»: рішення Європейського суду з прав людини від 30.10 .2003 р. № 31524/96. 
URL: http://hudoc.echr.coe.int/eng?i=001-58834 (дата звернення: 04.04.2019).

18. Справа «Beyeler v. Italy»: рішення Європейського суду з прав людини від 05.01.2000 p. № 33202/96. URL: http://hudoc.echr.coe.int/eng?i=001-58832 (дата звернення: 04.04.2019).

19. Справа «Broniowski v. Poland»: рішення Свропейського суду 3 прав людини від 28.09.2005 p. № 31443/96. URL: http://hudoc.echr.coe.int/eng?i=001-70326 (дата звернення: 04.04.2019).

20. Справа «Brumărescu v. Romania»: рішення Європейського суду 3 прав людини від 28.10 .1999 р. № 28342/95. URL: http://hudoc.echr.coe.int/eng?i=001-58337 (дата звернення: 04.04.2019).

21. Справа «Carmel Saliba v. Malta»: рішення Європейського суду 3 прав людини від 29.11.2016 р. № 24221/13. URL: http://hudoc.echr.coe.int/eng?i=001-169057 (дата звернення: 04.04.2019).

22. Справа «Former King of Greece and Others v. Greece»: рішення Європейського суду 3 прав людини від 23.11.2000 р. № 25701/94. URL: http://hudoc.echr.coe.int/eng?i=001-59051 (дата звернення: 04.04.2019).

23. Справа «Handyside v. the United Kingdom»: рішення Європейського суду 3 прав людини від 07.12.1976 р. № 5493/72. URL: http://hudoc.echr.coe.int/eng?i=001-57499 (дата звернення: 04.04.2019).

24. Справа «Hasan and Chaush v. Bulgaria»: рішення Європейського суду 3 прав людини. № 30985/96. URL: http://hudoc.echr.coe.int/eng?i=001-58921 (дата звернення: 04.04.2019).

25. Справа «Hentrich v. France»: рішення Свропейського суду 3 прав людини від 22.09.1994 p. № 13616/88. URL: http://hudoc.echr.coe.int/eng?i=001-57903 (дата звернення: 04.04.2019).

26. Справа «Jahn and Others v. Germany»: рішення Європейського суду з прав людини від 30.06.2005 р. № 46720/99, 72203/01, 72552/01. URL: http://hudoc.echr.coe.int/eng?i=001-69560 (дата звернення: 04.04.2019).

27. Справа «James and Others v. the United Kingdom»: рішення Європейського суду з прав людини від 21.02.1986 р. № 8793/79. URL: http://hudoc.echr.coe.int/eng?i=001-57507 (дата звернення: 04.04.2019).

28. Справа «Kleine Staarman v. the Netherlands»: рішення Європейського суду 3 прав людини від 16.05.1985 р. № 10503/83. 
URL: $\quad$ https://hudoc.echr.coe.int/app/conversion/pdf?library=ECHR\&i $\mathrm{d}=001-73885 \&$ filename $=$ F.P.J.M.\%20KLEINE\%20STAARMAN\%2 0v.\%20the\%20 NETHERLANDS.pdf (дата звернення: 04.04.2019).

29. Справа «Lars Bramelid and Anne Marie Malmström against Sweden»: рішення Комітету Міністрів від 25.10.1984 p. №№ 8588/79; 8589/79. URL: https://hudoc.echr.coe.int/eng\#\{"tabview": ["document"],"itemid":["001-49253"]\} (дата звернення: 04.04.2019).

30. Справа «Mellacher and Others v. Austria»: рішення Європейського суду 3 прав людини від 19.12 .1989 p. №oo 10522/83; 11011/84; 11070/84. URL: http://hudoc.echr.coe.int/ eng?i=001-57616 (дата звернення: 04.04.2019).

31. Справа «Рараmichalopoulos and Others v. Greece»: рішення Європейського суду з прав людини від 24.06.1993 р. № 14556/89. URL: http://hudoc.echr.coe.int/eng?i=001-57836 (дата звернення: 04.04.2019).

32. Справа «Pressos Compania Naviera S.A. and Others v. Belgium»: рішення Європейського суду 3 прав людини від 20.11.1995 p. № 17849/91. URL: http://hudoc.echr.coe.int/eng?i=00158056 (дата звернення: 04.04.2019).

33. Справа «Scollo v. Italy»: рішення Свропейського суду з прав людини від 28.09.1995 р. № 19133/91. URL: http://hudoc.echr.coe.int/ eng?i=001-57936 (дата звернення: 04.04.2019).

34. Справа «Solodyuk v. Russia»: рішення Європейського суду 3 прав людини від 30.11 .2005 р. № 67099/01. URL: http://hudoc.echr.coe.int/eng?i=001-69674 (дата звернення: 04.04.2019).

35. Справа «Sporrong and Lönnroth v. Sweden»: рішення Свропейського суду 3 прав людини від 23.09 .1982 p. №№ 7151/75; 7152/75. URL: http://hudoc.echr.coe.int/eng?i=001-57580 (дата звернення: 04.04.2019).

36. Справа «Stran Greek Rafineries and Stratis Andreadis v. Greece»: рішення Свропейського суду 3 прав людини від 09.12.1994 p. № 13427/87. URL: http://hudoc.echr.coe.int/eng?i=00157913 (дата звернення: 04.04.2019).

37. Справа «Suljagic v. Bosnia and Herzegovina»: рішення Свропейського суду з прав людини від 03.02.2010 р. № 27912/02. URL: http://hudoc.echr.coe.int/eng?i=001-95564 (дата звернення: 04.04.2019).

38. Справа «Svenska Managamentgruppen AB v. Sweden»: рішення Свропейського суду 3 прав людини від 01.12.1985 p. 
№ 11036/84. URL: https://hudoc.echr.coe.int/app/conversion/pdf ?library $=$ ECHR\&id $=001-72454 \&$ filename $=$ SVENSKA $\% 20 \mathrm{MANAGE}$ MENTGRUPPEN\%20AB\%20v.\%20SWEDEN.pdf (дата звернення: 04.04.2019).

39. Справа «Valkov and Others v. Bulgaria»: рішення Європейського суду з прав людини від 25.10.2011 р. № 2033/04, 19125/04, 19475/04, 19490/04, 19495/04, 19497/04, 24729/04, 171/05, 2041/05. URL: http://hudoc.echr.coe.int/eng?i=001-107157 (дата звернення: 04.04.2019).

40. Стеценко С.Г. Сучасний погляд на предмет адміністративного права. Публічне право. 2016. № 1. С. 20-26.

41. D'Aspermont J. Responsibility for Coups d'Etat in International Law. Tulane Journal of International and Comparative Law. 2010. № 18. Pp. 451-477.

42. Germany: Trend toward re-municipalisation of energy sector. URL: https://www.epsu.org/article/germany-trend-toward-remunicipalisation- energy-sector (дата звернення: 04.04.2019).

43. James W. What is Pragmatism?. / ed. by A. Blunden. USA: Harvard UP, 2005. 2193 p.

44. Kelsen H. General Theory of Law and State. Harvard: Harvard University Press. 2009. 516 p.

45. Varol O.O. The Democratic Coup d'Etat. Harvard International Law Journal. 2012. № 53. Pp. 292-356.

46. Welfens P.J.J. Economic Aspects of German Unification: National and International Perspectives. Berlin: Springer Verlag, 1992. $402 \mathrm{P}$.

\section{Information about the author: Zadyraka N. Yu. PhD in Law Science,} Associate Professor at the Administrative Law Department, Faculty of Law, Taras Shevchenko National University of Kyiv 